\title{
Konsep Guru Sejati dan Harmonisasi Kehidupan Dalam Legenda Masyarakat Dukuh Wonomulyo
}

\section{The Concept of a True Teacher and The Harmonization of Life in The Legend of Wonomulyo Hamlet Community}

\author{
Yunita Furinawati \\ Universitas PGRI Madiun \\ Alamat: Jalan Setia Budi No. 85, Kanigoro, Kartoharjo, Madiun, Indonesia 63118 \\ Email: yunitafurina@gmail.com
}

\begin{abstract}
Abstrak
Studi ini bertujuan untuk mengungkapkan bagaimana masyarakat Wonomulyo mengakui posisi guru sebagai perantara antara jagat besar dan jagat kecil. Fenomena cerita tentang asal mula suatu wilayah adalah permasalahan yang menarik untuk dikaji lebih mendalam. Cerita itu dianggap representasi kebudayaan di dalam suatu masyarakat. Sebuah cerita yang masih diyakini memiliki fungsi semacam itu adalah legenda Dukuh Wonomulyo. Cerita ini memiliki struktur yang unik, dimana setiap elemennya mecerminkan tatanan kehidupan masyarakat Wonomulyo. Metode etnografi digunakan dalam studi ini. Data kualitatif diperoleh melalui observasi partisipasi dan wawancara mendalam kepada informan warga masyarakat Wonomulyo serta text. Studi ini menerapkan paradigma strukturalisme melalui teori yang diformulasikan oleh Lévi-Strauss. Hasil studi ini menunjukkan bahwa Ki Hajar Wonokoso merupakan sosok sentral di dalam narasi cerita maupun kehidupan spiritual. Dia adalah guru bagi para keturunannya, yang tidak lain adalah orang-orang Wonomulyo sendiri. Semua ajaran kebajikannya yang diwarisi dan diamalkan oleh para keturunan, memberi mereka keselamatan dan kedamaian hidup serta harmonisasi kehidupan.
\end{abstract}

Kata kunci: legenda, guru, Ki Hajar Wonokoso, harmonisasi, strukturalisme, Wonomulyo

\begin{abstract}
This study aims to reveal how the Wonomulyo community recognizes the teacher's position as an intermediary between the big universe and the small universe. The phenomenon of stories about the origin of a region is an interesting problem to be studied in more depth. The story is considered a cultural representation in society. A story that is still believed to have such a function is the legend of Dukuh Wonomulyo. This story has a unique structure, where each element reflects the life order of the Wonomulyo people. The ethnographic method was used in this study. Qualitative data were obtained through participatory observation and in-depth interviews with Wonomulyo community informants and text. This study applies the structuralism paradigm through the theory formulated by Lévi-Strauss. The results of this study indicate that Ki Hajar Wonokoso is a central figure in the narrative story and spiritual life. He is a teacher for his descendants, who are none other than the Wonomulyo people themselves. All the teachings of his virtues are inherited and practiced by the descendants, giving them safety and peace of life and harmonization of life.
\end{abstract}

Keywords: legend, teacher, Ki Hajar Wonokoso, harmonization, structuralism, Wonomulyo

Biokultur, 2021, 10 (2): 85-96. DOI: http://dx.doi.org/10.20473/bk.v10i2.31713

Article History:

Received November 27, 2021; Accepted November 29, 2021; Published Online December 22, 2021. 


\section{Pendahuluan}

Studi ini bertujuan untuk membahas fenomena tradisi lisan berupa legenda Dukuh Wonomulyo. Dewasa ini, Dukuh Wonomulyo yang ter terletak di Desa Genilangit, Kecamatan Poncol, Kabupaten Magetan terkenal dengan wisata alam dengan tajuk negeri di atas awan. Dukuh yang terletak pada ketinggian 1240 di atas permukaan ini memang menyuguhkan keindahan alam yang luar biasa. Namun, dibalik keindahan alam yang ditawarkan oleh Dukuh Wonomulyo, terdapat satu cerita rakyat yang masih berkembang hingga sekarang. Pada umumnya cerita rakyat dapat dianggap cerita fiktif murni, tetapi juga terinspirasi oleh peristiwa-peristiwa sejarah dan selebihnya dipengaruhi mitos dan legenda tergantung peristiwa yang melatarbelakanginya (Sari et al, 2017). Legenda erat kaitannya dengan asal-usul suatu tempat. Legenda dipercaya benar-benar terjadi di dalam konteks masyarakat pemiliknya. Tokoh-tokoh legenda dipercaya sebagai nenek moyang masyarakat tertentu. Menurut Danandjaja (2007:67) legenda adalah prosa rakyat yang diyakini pernah terjadi dan memiliki kaitan dengan asal usul suatu daerah. Legenda memiliki sifat migratoris yang mampu berpindah dan mudah dikenal atau pun disebarluaskan di lain daerah.

Dukuh Wonomulyo pada awalnya bernama Jeblog. Pada tahun 1983 nama Jeblog diubah menjadi Wonomulyo. Wonomulyo berasal dari kata wana dan mulya yang memiliki berarti hutan yang makmur dianggap lebih bagus dan merepresentasikan kondisi dukuh tersebut. Penelitian ini menggunakan istilah legenda Dukuh Wonomulyo dengan alasan nama Wonomulyolah yang dipakai sekarang dan lebih dikenal oleh masyarakat luas. Tujuan penelitian ini secara khusus adalah membongkar struktur legenda Dukuh Wonomulyo. Melalui struktur-struktur tersebut ditemukan elemen-elemen unuk terkait bagaimana konsep kehidupan masyarakat Dukuh Wonomulyo. Konsep yang ditemukan dalam kajian struktur legenda Dukuh Wonomulyo adalah peran utama tokoh sentral dalam masyarakat Dukuh Wonomulyo yaitu Ki Hajar Wonokoso.

\section{Metode}

Konsep penting mengenai strukturalisme Lèvi-Strauss adalah konsep struktur dan transformasi. Lèvi-Strauss mengatakan bahwa struktur adalah model yang dibuat oleh Antropologi untuk memahami dan menjelaskan gejala kebudayaan yang dianalisis. Dalam analisis struktural, struktur dibedakan menjadi struktur lahir (luar) dan struktur batin (dalam). Struktur luar adalah relasi antar unsur yang dapat di bangun dari ciri-ciri luarnya, sedangkn struktur dalam merupakan susunan tertentu yang kita bangun berdasarkan struktur lahir. Selain struktur dalam dan luar, terdapat pula transformasi, pengertian transformasi di sini adalah penggantian elemen yang membentuk struktur, ataupun hilangnya elemen di dalamnya.

Berbagai fenomena budaya terwujud oleh strukturasi, termasuk mitos yang dalam pengertian strukturalisme Lèvi-Strauss tidak sama dengan kajian mitologi. Mitos di sini adalah sesuatu yang tidak perlu diperdebatkan dengan sejarah dan kenyataan dan bukan merupakan cerita-cerita yang suci, mitos melainkan sebuah dongeng. Dongeng sendiri merupakan cerita khayalan manusia, yang diekspresikan secara bebas oleh penciptanya. Analisis mitos, diharapkan menemukan struktur dalam mitos yang menunjukkan keinginan-keinginan yang tidak di sadari dan merupakan ekspresi dari sebuah kekangan. 
Adanya analisis struktural yang dikembangkan oleh Lèvi-Strauss menimbulkan banyak kritik, yakni kritik terhadap perangkat metode analitik. Kritik terhadap data etnografi dan interprestasinya, serta kritik terhadap hasil analisis serta kesimpulannya (Ahimsa 2006). Data etnografi dalam penelitian ini didapatkan melalui proses metode wawancara mendalam (depth interview) digunakan dalam memperoleh data. Peneliti harus menjadi satu diantara mereka (one of them). Peneliti terlibat langsung dalam kehidupan masyarakat dukuh Wonomulyo termasuk terlibat dalam ritual Galungan. Subjek penelitian adalah sesepuh desa dan dukun desa di dukuh Wonomulyo. Masyarakat yang diwawancarai disebut dengan subjek penelitian karena langsung terkait dengan kehidupan setempat. Subjek penelitian dalam kajian ini adalah seluruh Masyarakat Wonomulyo yang meyakini keberadaan Ki Hajar Wonokoso.

Selanjutnya teks lisan yang didapatkan terkait legenda dalam Dukuh Wonomulyo tersebut didengarkan secara berulang-ulang dan dilakukan proses transkripsi. Transkripsi yang dilakukan menggunakan pemindahan secara setia dimana semua yang disampaikan oleh informan dan narasumber dialaih mediakan menjadi bentuk tulis. Guna mempermudah pembacaan, transkripsi fonetis dilakukan dengan menggunakan kaidan fonetik bahasa Jawa. Hasil transkripsi tersebut kemudian diterjemahkan ke dalam bahasa Indonesia. Penerjemahan dilakukan dengan menggunakan kamus bahasa Jawa-Indonesia dan kamus bahasa Jawa Kuna. Selain itu penerjemakan juga memandang konteks masyarakat Dukuh Wonomulyo. Hasil dari proses terjemahan legenda Dukuh Wonomulyo inilah yang kemudian dilakukan pembacaan retroaktif untuk menemukan bagaimana struktur yang terdapat didalamnya. Struktur-struktur dalam legenda Dukuh Wonomulyo tersebut dianalisis menggunakan strukturalisme Lèvi-Strauss.

\section{Hasil Penelitian dan Pembahasan}

\section{Legenda Ki Hajar Wonokoso}

Dikisahkan pada suatu hari seorang pertapa bernama Ki Hajar Wonokoso sedang bepergian berdua dengan istrinya dengan mengendarai angin. Mereka ingin mencari tempat baru untuk mendirikan sebuah pertapaan. Sesampainya di lereng Hargo Cupu, angin yang mereka kendarai mendadak berhenti dan jatuhlah mereka ke sebuah padang rumput yang hijau. Tempat dimana mereka berdua jatuh tersebut dinamakan jeblog (jatuh) oleh Ki Hajar Wonokoso. Nama jeblog digunakan untuk menandai bahwa di tempat itulah mereka dijatuhkan untuk memulai kehidupan baru. Ki Hajar Wonokoso dan istri memutuskan untuk tinggal di tempat tersebut. Mereka membangun sebuah pertapaan dan mejalani kehidupan sehari-hari.

Mendengar seorang pertapa yang sakti menetap di lereng Hargo Cupu, datanglah lima orang untuk berguru kepadanya. Lima orang tersebut bernama Kyai Jemat Ki Ageng Gethok Keling, Budha, Tedjowiryo, Wironiti, Saranti dan Sarani. Selain kelima murid tersebut masyarakat lain berdatangan ke Jeblog. Mereka memulai hidup baru dengan bercocok tanam. Kehidupan mereka makmur tanpa kekurangan. Ki Hajar Wonokoso dianggap sebagai guru yang memiliki wawasan luas dan kesaktian luar biasa. Semua nasihat dan petuah Ki Hajar Wonokoso dipatuhi termasuk larangan-larangan darinya. Beberapa larangan yang harus diingat oleh masyarakat Jeblog adalah tidak menanam kelapa dan padi. Karena kedua tanaman tersebut tidak akan berbuah apabila di tanam di Jeblog. Selain itu, Ki Hajar Wonokoso juga melarang semua masyarakat Jeblog untuk 
mengingkari janji. Apabila larangan tersebut dilanggar, maka akan mendapatkan petaka bagi pelakunya.

Berpuluh tahun Ki Hajar Wonokoso menetap di Jeblog dengan perasaan bahagia memandang masyarakatnya yang semakin hidup makmur. Suatu hari, Ki Hajar Wonokoso berpamitan kepada istrinya untuk pergi pertapa. Dia berpesan bahwa ketika dia pulang bertapa nanti harus disiapkan tumpeng dari nasi jagung, tempe bakar, botok ares, dan gandikan (kudapan dari jagung). Nyi Hajar wonokoso menyanggupi permintaan tersebut dan melepas kepergian suaminya. Waktu berlalu, setelah beberapa bulan lamanya bertapa akhirnya Ki Hajar Wonokoso pulang ke padepokannya. Kepulangannya disambut oleh Nyi Hajar Wonokoso dengan makanan yang telah dibuat sesuai perintah dari suaminya. Namun, sajian itu tidak dimakan oleh Ki Hajar Wonokoso.

Ki Hajar Wonokoso langsung mengumpulkan semua murid untuk mendengarkan pesannya bahwasanya ajalnya sudah dekat. Dia berpesan apabila kelak meninggal maka jasadnya harus dikremasikan. Abu kremasi hendaknya dibagi menjadi dua bagian, sebagian disebarkan di atas tanah. Apabila kemudian muncul jejak kaki binatang dari abu yang disebarkan tersebut maka sebagian abunya harus dilarung di laut. Jejak binatang melambangkan keangkaramurkaan maka segera jauhkanlah dari Jeblog. Namun, apabila muncul jejak bayi pada permukaan abu maka sisa abu lainnya harus disebarkan ke empat penjuru mata angin. Jejak bayi melambangkan kemakmuran, maka dekatkanlah dengan Jeblog. Demikianlah pesan tersebut disampaikan oleh Ki Hajar Wonokoso.

Tepat pada hari Selasa Wage di Wuku Galungan Ki Hajar Wonokoso wafat. Seluruh warga jeblog bersedih. Nyi Hajar Wonokoso beserta para segera mempersiapkan upacara kremasi untuk jasad Ki Hajar Wonokoso. Usai upacara kremasi, para murid berkumpul untuk menjalankan perintah mendiang guru mereka. Abu hasil kremasi dibagi menjadi dua bagian. Satu bagian disebrkan ke tanah. Mereka menunggu jejak apa yang muncul dari permukaan abu. Ternyata jejak yang muncul adalah telapak bayi. Seluruh warga jeblog bergembira karena semua kebaikan yang telah diberikan oleh Ki Hajar Wonokoso tetap bersama mereka. Para murid kemudian menyebarkan sisa abu ke empat penjuru mata angin. Tempat disebarkannya abu tersebut kemudian menjadi makam Ki Hajar Wonokoso. Disanalah semua pusaka dan seluruh kitabnya ikut dimakamkan. Sejak itulah hari Selasa Wage di Wuku Galungan diperingati oleh seluruh masyarakat Jeblog untuk mengenang kepergian guru sekaligus pemimpin mereka. Peringatan itu dikenal sampai sekarang dengan ritual "Galungan".

\section{Konsep Guru dan Murid dalam Legenda Dukuh Wonomulyo}

Tokoh utama dalam Legenda dukuh Wonomulyo adalah Ki Hajar Wonokoso. Terdapat sebutan Ki Hajar yang disematkan sebelum nama Wonokoso. Sapaan Ki, diawal nama adalah lazim digunakan oleh masyarakat Jawa untuk laki-laki yang berusia lebih tua (kaki). Sapaan inilah kemudian oleh mayarakat Wonomulyo dikembangkan menjadi "Eyang" yang dianggap lebih representative dengan zamannya. Masyarakat dukuh Wonomulyo sendiri tidak menggunkan sapaan "eyang" untuk memanggil kakek nenek. Mereka menggunakan sapaan "mbah" atau "nang e". Sapaan "eyang" dianggap hanya digunakan oleh kaum bangsawan dan kaum priyayi saja. Selanjutnya, terdapat kata "Hajar" setelah sapaan "Ki" di nama KI Hajar Wonokoso juga memiliki makna yang istimewa. Dalam bahasa Jawa, hajar berasal dari kata ajar yang memiliki 
arti sebuah pertapaan atau bisa merujuk pada seseorang yang melatih diri dengan tekun dalam melepaskan diri dari keduniawiannya (Zoetmulder dan Robson, 2006: 16). Sebutah Hajar biasanya diberikan oleh masyarakat Jawa kepada tokoh-tokoh yang memiliki kontribusi besar dalam bidang keilmuan. Konteks ilmu yang dimaksud tidak hanya ilmu yang bersifat empiris namun juga "ilmu" yang diyakini bersifat ghaib.

Sebutan Ki Hajar dalam Ki Hajar Wonokoso menunjukkan posisinya yang dianggap istimewa karena memiliki kecakapan di bidang keilmuan. Di dalam legenda Dukuh Wonomulyo disebutkan bahwa Ki Hajar Wonokoso mendirikan sebuah pertapaan, kemudian murid-murid datang untuk menuntut ilmu. Kehadiran tokoh Kyai Jemat Ki Ageng Gethok Keling, Budha, Tedjowiryo, Wironiti, Saranti dan Sarani sebagai murid menguatkan bahwa Ki Hajar Wonokoso dianggap sebagai guru di Dukuh Wonomulyo. Masyarakat Dukuh Wonomulya memaknai guru sebagai idiom dari digugu dan dituru. Sesesorang bisa angkat menjadi guru ketika dianggap mampu memberikan ajaran kebaikan dan ditiru semua kebijakan prilakunya. Konsep guru dalam masyarakat Dukuh Wonomulyo yang terkesan sederhana namun memiliki makna mendalam. Proses untuk mencapai digugu dan dituru inilah yang begitu berat. Seorang guru sejati harus menempuh laku yang panjang.

Laku dilakukan seorang guru untuk menemukan konsep kesempurnaan hidup. Kesempurnaan hidup yang dimaksud adalah proses mencapai keselarasan antara semua tingkah laku kehidupan dengan alam dan Tuhannya. Terkait dengan konsep keselarasan tersebut Mulder (2001:41) masyarakat jawa memimpikan adanya penyatuan secara individu dengan Tuhannya, proses penyatuan tersebut tidak mungkin tercapai tanpa adanya penyelarasan dengan masyarakat dan lingkungan sekitar. Proses penyatuan tersebut dilakukan secara individu atau pun secara sosial demi mencapai ketentraman dan keharmonisan. Dalam Legenda Dukuh Wonomulyo disebutkan bahwa Ki Hajar Wonokoso pergi ke hutan untuk bertapa. Proses bertapa inilah salah satu laku yang dilakukan oleh Ki Hajar Wonokoso.

Bertapa atau dalam budaya Jawa sering disebut tapa brata merupakan proses dimana seseorang berusaha untuk memahami sesuatu dalam kondisi diam. Konsep menep dan menep diterapkan dalam sebuah tapa brata. Meneng (Bahasa Jawa: diam) adalah proses bagaimana manusia berusaha untuk berdiam diri. Berdiam diri bukan hanya dimaknai berhenti dari aktifitas ragawi, namun lebih kepada mengistirahatkan pikiran. Pikiran yang diistirahatkan dari masalah keduawian maka akan mampu untuk lebih memaknai konsep ke-Tuhanan dan ke-akuan dalam diri manusia. Selanjutnya adalah menep (Bahasa Jawa: mengendap) adalah proses penyerapan semua makna kehidupan. Proses ini adalah lanjutan dari meneng. Setelah berhasil untuk memaknai ke-Tuhanan dan ke-akuan maka hasil tersebut akan diendapkan dalam diri manusia tersebut untuk kemudian dipisahkan antara yang baik dan buruk. Kebaikan akan terus dipraktikkan dan diajarkan dalam kehidupan sedangkan segala keburukan harus diendapkan dan dikendalikan.

Ki Hajar Wonokoso yang pergi bertapa mengelola raga dan pikirannya dalam proses meneng dan menep. Semua yang didapat dari proses pertapaan tersebut diajarkan kepada murid-muridnya. Ajaran kebaikan dan larangan muncul dalam proses pembelajaran Ki Hajar Wonokoso terhadap murid-muridnya. Salah satu ajaran Ki Hajar Wonokoso adalah menepati janji yang diucapkan kepada orang lain. Menepati merupakan hal utama yang harus dilakukan untuk menjaga 
keharmonisan kehidupan. Selain ajaran, muncul juga larangan-larangan yang harus diterapkan dalam menjaga keharmonisan dengan alam yaitu tidak menanam padi dan kelapa di Dukuh Wonomulyo. Ajaran dan larangan tersebut apabila dilanggar akan mendatangkan mala petaka. Pola hubungan antara guru dan murid dalam legenda Dukuh Wonomulyo adalah:

Guru---maha tahu--memberi ajaran--harus dilakukan $\vec{\searrow}$ melanggar ajaran--mendapat petaka Murid---mencari tahu--menerima ajaran--harus dilakukan $>$ melanggar ajaran--mendapat petaka $\checkmark$ mematuhi ajaran--mendapat pahala

Pola hubungan guru dan murid tersebut menunjukkan bahwa seorang guru yang memiliki wawasan luas hasil dari laku tapa brata berekwajiban untuk memberi tahu kepada muridnya. Informasi yang diberikan tersebut berisi perintah untuk melakukan kebajikan dan menghindari hal-hal buruk. Konsekuensinya, seorang guru harus menjadi contoh yang baik bagi muridnya dengan menjalankan semua ajarannya. Apabila seorang guru melanggar apa yang dia ajarkan maka guru tersebut akan mendapatkan petaka. Sebaliknya, apabila seorang guru mematuhi semua yang dia ajarkan maka akan mendapatkan pahala. Di lain pihak seorang murid bertugas mencari tahu tentang konsep ilmu yang belum dipahaminya. Murid menerima ajaran yang terkait dengan kebajikan dan larangan-larangan. Petaka didapatkan ketika murid tidak mematuhi semua yang diajarkan oleh guru. Sedangkan pahala didapatkan ketika murid mematuhi semua yang diajarkan oleh guru. Dari pola tersebut diketahui bahwa perbedaan antara guru dan murid hanya terletak kepada tingkat pengetahuan saja. Kewajiban dan konsekuensi terhadap sebuah ajaran sama. Ketika guru dan murid melanggar ajaran maka mendapatkan petaka sedangkan ketika mematuhinya mendapatkan pahala.

Ki Hajar Wonokoso yang telah melakukan laku dalam hidupnya oleh masyarakat Dukuh Wonomulyo dianggap sebagai sosok yang dekat dengan Tuhan. Terkait dengan kepercayaan kepada Tuhan, masyarakat Dukuh Wonomulyo terbagi atas dua keyakinan yaitu Islam dan Budha. Kedua agama tersebut masuk di Dukuh Wonomulyo setelah tahun 1965 dimana pemerintah Indonesia mewajibkan seluruh warga negaranya untuk mencantumkan keterangan agama dalam kartu tanda penduduk. Perintah ini menjadi pilihan yang sulit bagi masyarakat Dukuh Wonomulyo. Sebagian langsung memilih Islam sebagai agama mereka, sedangkan lainnya merasa kebingungan dalam menentukan agama. Hindu menjadi pilihan pertama karena masyarakat Dukuh Wonomulyo memiliki ritual Galungan. Namun, seiring berjalannya waktu keyakinan yang dianut oleh masyarakat Dukuh Wonomulyo berbeda dengan ajaran Hindu Bali. Selanjutnya, dalam pencarian agama tersebut masyarakat Dukuh Wonomulyo menemukan ajaran agama baru diluar Islam dan Hindu, yakni Budha. Masyarakat yang semula memeluk agama Hindu inilah pada akhirnya memilih agama Budha. Sebuah Vihara dibangun di Dukuh Wonomulyo untuk menandakan keaktifan kegiatan keagamaan Budha di sana.

Proses bagaimana masyarakat Dukuh Wonomulyo dalam menentukan agama sesungguhnya tidak berpengaruh pada keyakinan mereka terhadap Ki Hajar Wonokoso. Ki Hajar Wonokoso tetaplah dianggap sebagai sosok perantara yang dikirimkan oleh Tuhan untuk menjaga kemakmuran Dukuh Wonomulyo. Kesaktian yang dimiliki oleh Ki Hajar Wonokoso dianggap sebagai kesaktian tak tertandingi dan sejajar dengan apa yang dimiliki oleh Tuhan. Masyarakat dukuh Wonomulyo menganggap Ki Hajar Wonokoso sebagai perwakilan Tuhan. Ki Hajar 
Wonokoso tidak dikisahkan memiliki silsilah yang jelas, bahkan terkait dengan kerajaan Mataram. Menurut Laksono (2009: 71) mengemukakan bahwa wilayah mancanegara Mataram disebelah timur terdiri dari: Panaraga, Kediri, Madiun, Pacitan, Kaduwang, Caruban, Pace, Kersan, Sarengat dan Blitar, Jipang, Grobogan, Warung, Sela, Blora, Rawa (Tulungagung), Barebeg, Jagaraga, Kalangbret, Japan, Majakerta, Wirasaba (Majaagung). Walaupun sejarah mencatat bahwa Kabupaten Magetan erat kaitannya dengan kebudayaan Mataraman, namun hal tersebut tidak berlaku bagi sosok Ki Hajar Wonokoso.

Keyakinan masyarakat Dukuh Wonomulyo terkait sosok Ki Hajar Wonokoso sebagai utusan Tuhan acapkali menimbulkan cap "kejawen" pada masyarakatnya. Istilah "kejawen" lazim digunakan di Magetan untuk menyebut golongan masyarakat yang dianggap masih patuh terhadap tradisi yang dimiliki. Kepatuhan tersebut melebihi tradisi keagamaan yang dianut. Sebagai contoh, seseorang dengan identitas keagamaan Islam tidak menjalankan salat lima waktu namun menjalankan selamatan, Samadhi, tapa, puasa mutih, mengunjungi pundhen, ngalap berkah dll maka orang tersebut akan disebut "kejawen". Menurut Geertz (1989:5) masyarakat Jawa secara biografi merupakan wilayah di pulau Jawa yaitu: Jawa Barat, Jawa Tengah, Yogyakarta dan juga Jawa Timur. Sebelum terjadinya status wilayah di atas daerah-daerah tersebut telah identik dengan istilah kejawen ataupun pesisir dan ujung timur. Masyarakat dukuh Wonomulyo menolak sebutan "kejawen" untuk menandai apa yang mereka anut dan yakini. Keyakinan yang mereka anut tidak bisa dianamai begitu saja. Paabila ingin menyebut status keagamaan mereka lebih memilih untuk disebut sebagai pemeluk agama Islam atau pun Budha. Ketakutan akan sebutan "kejawen" ini merupakan kelanjutan pasca peristiwa G30S/PKI. Ketakutan akan sebutan tidak beragama yang berdampak pada aksi pelenyapan membuat warga Dukuh Wonomulyo menolak apabila disebut "kejawen".

Masih terkait dengan kepercayaan, sampai sekarang masyarakat dukuh Wonomulyo tetap mensakralkan makam Ki Hajar Wonokoso. Makam tersebut menjadi pundhen bagi masyarakat dukuh Wonomulyo. Pundhen berarti junjungan atau apa yang dijunjung tinggi serta dihormati (Prawiroatmodjo, 1981: 118). Masyarakat dukuh Wonomulyo sangat menghormati makam Ki Hajar Wonokoso. Terdapat kebiasaan bagi masyarakat Dukuh Wonomulyo yang hendak pergi menrantau untuk berpamitan ke makam Ki Hajar Wonokoso. Mereka meminta berkah dan perlindungan dari Ki Hajar Wonokoso. Sebelum pulang dari makam Ki Hajar Wonokoso, para calon perantau ini membawa sedikit tanah dari makam. Tanah tersebut kemudian dijadikan sebagai azdimat yang diyakini akan memberikan perlindungan dimanapun mereka berada.

Permohonan akan keselamatan, berkah, dan kemakmuran di tujukan kepada Ki Hajar Wonokoso ketika ritual Galungan. Galungan merupakan nama sebuah wuku dalam kalender Jawa. Masyarakat Jawa mengenal 30 wuku. Satu wuku memiliki masa siklus selama 7 hari. Sedangkan tepat pada hari ke 210 sikul suku kembali ke awal. Wuku Galungan identik dengan makna kemenangan atau pertempuran (Wiana, 2001: 12). Ritual untuk mengenang meninggalnya Ki Hajar Wonokoso ini memiliki posisi penting dibandingan dengan perayaan hari raya Idul Fitri dan Waisak. Dalam ritual Galungan masyarakat Dukuh Wonomulyo yang telah akhil baliq diwajibkan untuk hadir. Hal ini berlaku untuk semua masyarakat baik yang sedang merantau atau pun yang tinggal di Dukuh Wonomulyo.

Dalam ritual Galungan, masyarakat Dukuh Wonomulyo melakukan selamatan di area makam Ki Hajar Wonokos. Secara etimologis selametan merujuk pada kata selamet yang berarti 
kedamaian, berkah, dan ketenangan di jalan mistik menuju Tuhan (Woodward, 2011: 121). Tujuan masyarakat dukuh Wonomulyo menghadiri selamatan dalam rangkaian ritual Galungan adalah ngalap berkah atau mencari berkah yang terkait pada kemakmuran sandang, pangan, papan. Namun, bagi sebagian orang tidak hanya berkah sandang, pangan, dan papan saja yang diminta dalam ritual Galungan. Beberapa permintaan khusus juga dipanjatkan kepada Ki Hajar Wonokoso ketika ritual Galungan. Permintaan khusus ini biasanya disertai dengan janji-janji tertentu. Sebagai contoh, permintaan ingin memiliki anak dengan janji khusus menyembelih sapi di makam Ki Hajar Wonokoso apabila permintaanya terkabul. Hubungan Gusti Pengeran, Ki Hajar Wonokoso, dan masyarakat Dukuh Wonomulyo digambarkan selaiknya segitiga terbalik seperti berikut:

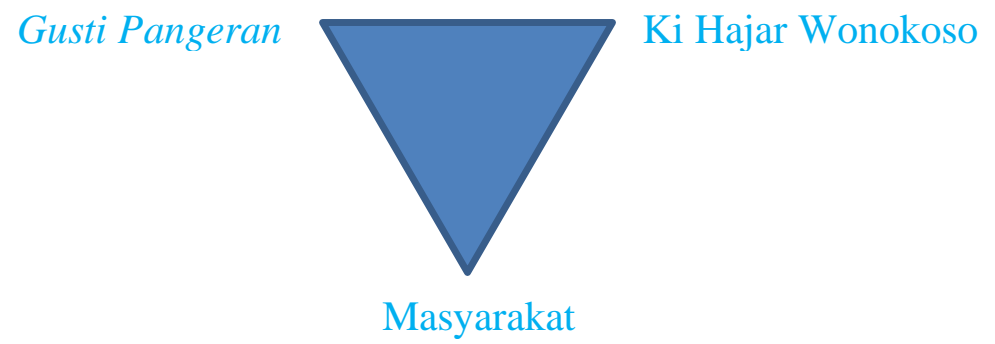

Gambar 1. Keyakinan Masyarakat Dukuh Wonomulyo

Masyarakat Dukuh Wonomulyo meyakini adanya kekuatan besar diluar kekuatan manusia. Kekuatan tersebut tidak bisa dijelaskan bagaimana sistemnya dalam memberikan berkah kepada masyarakat Dukuh Wonomulyo. Diyakini kekuatan maha besar yang tidak bisa dijelaskan tersebut berasal dari Gusti Pengeran. Kemunculan tokoh Ki Hajar Wonokoso yang direpresentasikan dalam legenda memiliki kesaktian dan keluasan wawasan. Representasi inilah yang lebih mudah memberikan gambaran akan sosok yang dianggap mempu melindungi masyarakat Dukuh Wonomulyo. Namun, masyarakat Dukuh Wonomulyo tidak pernah menganggap Ki Hajar Wonokoso sebagai Gusti Pengeran. Posisi Ki Hajar Wonokoso adalah perwakilan Gusti Pengeran di dunia. Laku yang dijalankan oleh Ki Hajar Wonokosolah yang membuatnya menjadi wakil dari Gusti Pengeran dan mampu menyatu dengan Gusti Pengeran.

Setelah Ki Hajar Wonokoso dan para murid meninggal, posisi pemimpin sekaligus guru di Dukuh Wonomulyo digantikan oleh seorang pinisepuh atau disebut juga sebagai wong tuwa. Bagi masyarakat Wonomulyo, pinisepuh adalah orang yang dianggap telah menguasai rasa. Rasa merupakan kekuatan yang mampu menghubungkan manusia dengan Tuhannya, karena dengan rasa manusia belajar menghayati apa yang telah diberikan oleh Tuhan dan dilakukan untuk Tuhan. Mulder (2001: 128) secara mistis maupun praktis, rasa bisa dideskripsikan sebagai perasaan kedalaman intuitif yang dipunyai semua orang. Rasa akan berkembang sebagi instrumen untuk mengantar pada wawasan sejati yang merupakan peran dan hakikat seseorang dan peran seseorang dalam Sang Hakikat. Tidak semua masyarakat Dukuh Wonomulyo mampu mnegndalikan rasa. Hanya masyarakat-masyarakat yang dianggap memiliki wahyu dari Ki Hajar Wonokoso saja yang mampu melakukannya. Orang terpilih tersebut kemudian menjadi sesepuh desa yang dalam perkembangannya dipercayai juga memiliki kekuatan untuk menyembuhkan penyakit. 
Pinisepuh memiliki tugas suci dalam mencaga budaya Dukuh Wonomulyo. Tugas utamanya tidak hanya sebagai pemimpin ritual semata, namun juga sebagai pengawas tata kehidupan di Dukuh Wonomulyo. Peran pinisepuh sama seperti peran seorang guru, yang harus mampu membimbing seluruh masyarakat Dukuh Wonomulyo ke arah kebaikan. Namun, hadirnya sosok guru dalam diri pinisepuh ini bagi masyarakat Dukuh Wonomulyo tidak mampu untuk menandingi guru sejati mereka: Ki Hajar Wonokoso.

\section{Konsep Harmonisasi Kehidupan dalam Legenda Dukuh Wonomulyo}

Masyarakat Dukuh Wonomulyo memiliki keseimbangan sendiri dalam hubungannya dengan sesama dan alam semestanya. Hubungan ini dapat dilihat dari simbol-simbol yang muncul dalam legenda Dukuh Wonomulyo. Keharmonisan hubungan antara mansusia dengan sesama dan lingkungan dalam filsafat Jawa disebut sebagai harmonisasi jagad alit dan jagad gedhe. Mulder (2001) mengemukakan bahwa tatanan merupakan salah satu struktur terpenting dalam pengalaman kejawaan. Tatanan tersebut disusun sedemiakian harmonis untuk mencapai keharmonisan antara jagad cilik atau dunia fana (micro-cosmos) dengan jagad gedhe atau dunia abadi (macro-cosmos).

Dukuh Wonomulyo terletak di lereng Gunung Hargo Cupu. Letak dukuh ini sangat menarik karena dikelilingi oleh dikelilingi oleh empat gunung dan satu gunung sebagai pusatnya. Gunung tersebut adalah Gunung Kendil yang berada di utara, Gunung Kukusan yang berada di timur, Gunung Puncak Dhalang berada di selatan, Gunung Larangan yang berada di barat dan Gunung Hargo Cupu yang berada di tengah. Sama seperti empat gunung dan satu gunung sebagai porosnya, demikian halnya dengan pembagian wilayah di Wonomulyo. Dukuh Wonomulyo dibagi menjadi lima bagian yaitu: Nglorokan di utara, Kuning di timur, Gedangan di selatan, Larangan di barat dan Genthong di tengah.

Posisi penataan yang didasari angka lima tersebut apabila dihubungkan dengan kepercayaan masyarakat Wonomulyo mengenai adanya sifat manusia yang berhubungan dengan penghitungan hari. Empat sifat dasar nafsu manusia juga mewakili penghitungan pasaran dan unsur alam. Soesilo (2005:198), aluamah, jatuh pada hari pasaran wage, mewakili unsur tanah, dan berpusat di utara. Mutmainah, jatuh pada pasaran legi, berunsur air, dan berpusat di timur. Amarah, jatuh pada pasaran Paing, berunsur api dan berpusat di selatan. Supiah, jatuh pada pasaran Pon, mangandung unsur angin dan berpusat di barat. Keempat nafsu tersebut hanya bisa dikendalikan oleh rasa atau diri dengan pasaran Kliwon, yang berpusat ditengah. Apabila digambarkan dalam sebuah diagram, tata letak Dukuh Wonomulyo sebagai berikut: 


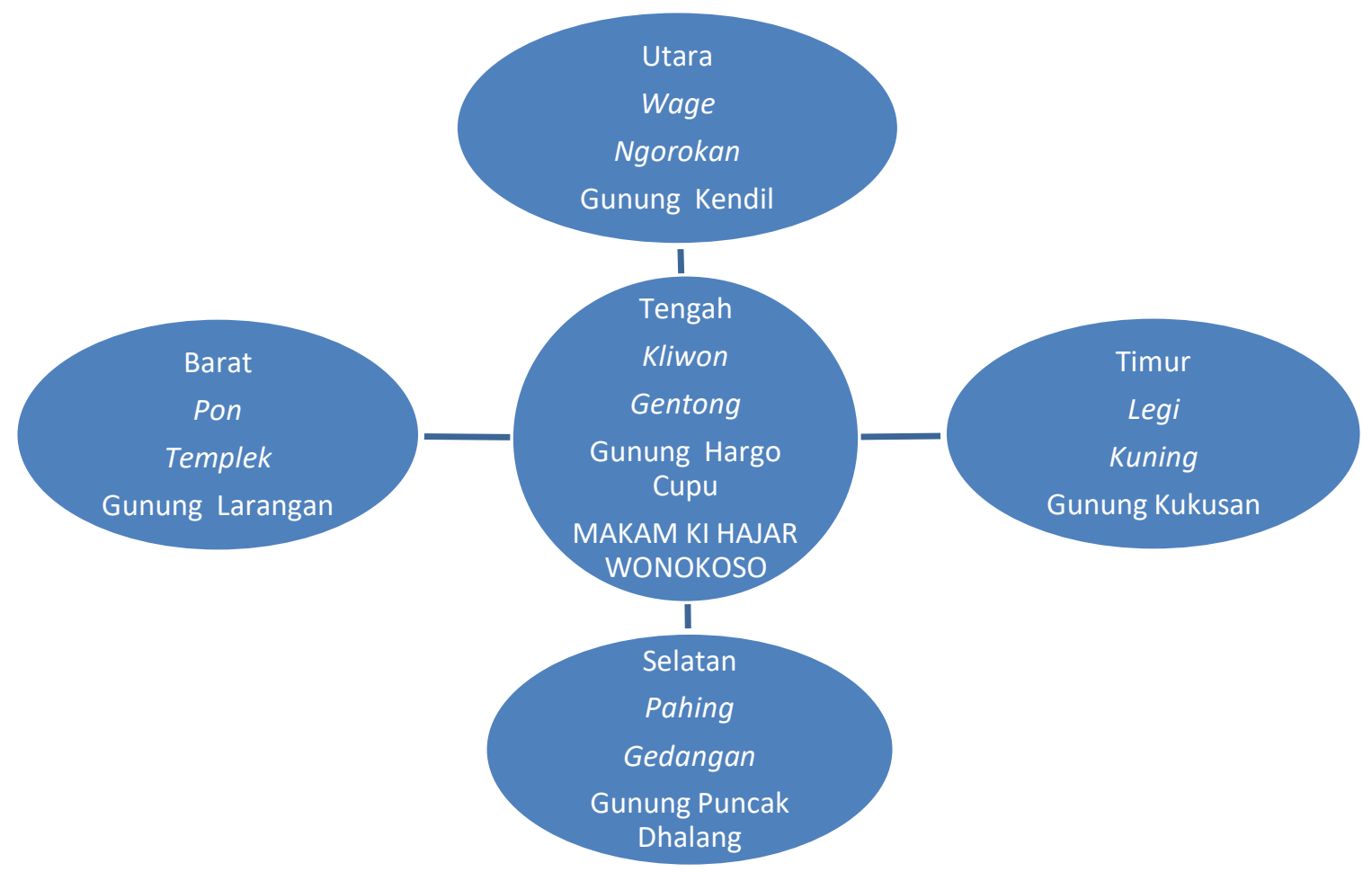

Gambar 2. Diagram Letak Dukuh Wonomulyo

Menurut diagram di atas, dapat dilihat bagaimana letak Dukuh Wonomulyo terkait dengan arah mata angin, pasaran, dan sifat yang menyertainya. Pasaran yang digunakan dalam konsep tata letak Dukuh Wonomulyo menggunakan tanggalan Jawa. Semula tanggalan jawa digunakan untuk menentukan waktu untuk menandai peribadahan. Namun, sekarang telah beralih fungsi untuk menentukan hari baik, tata letak, hari nahas, dan lain sebagainya (Nisa', 2021). Legenda Dukuh Wonomulyo menyebutkan bahwa abu jenasah Ki Hajar Wonokoso disebar ke seluruh penjuru mata angin. Ki Hajar Wonokoso berpesan abu tersebutlah yang melindungi masyarakat Dukuh Wonomulyo dari mara bahaya. Tempat pertama abu Ki Hajar Wonokoso disebarkan kemudian dijadikan makam terletak di wilayah Gentong dan lereng Hargo Cupu. Secara sekilas mata, lokasi makam Ki Hajar Wonokoso berada di daerah paling tinggi di ujung barat Dukuh Wonomulyo. Namun, apabila dilihat dari keseluruhan wilayah Dukuh Wonomulyo letak makam tersebut tepat di tengah perdukuhan. Letak ditengan ini mencerminkan bagaiman Ki Hajar Wonokoso diposisikan berada di tengah-tengah masyarakat Dukuh Wonomulyo. Ki Hajar Wonokoso diharapkan mampu selalu menengahi segala permasalahan yang mucul akibat kelima sifat hidup manusia.

Masyarakat Dukuh Wonomulyo hidup saling berdampingan. Mereka mengenal sistem sambatan. Dalam bahasa Jawa sambatan berasal dari kata sambat+an yang berarti mengeluh atau mengadu. Sistem sambatan di Dukuh Wonomulyo dilakukan ketika seseorang sedang membutuhkan bantuan seperti mendirikan rumah, panen, memperbaiki makam, khitanan, dan pernikahan. Orang yang memiliki acara tersebut meminta tolong kepada tetangga-tenagganya. Tetangga yang dibutuhkan membantu dengan tenaga suka rela tanpa dibayar. Sambatan yang biasanya 
dilakukan tidak lebih dari dua hari inilah salah satu upaya masyarakat Dukuh Wonomulyo untuk menjaga hubungan baik dengan sesama tetangga.

Harmonisasi masyarakat Masyarakat Dukuh Wonomulyo tidak hanya terjalin dengan sesama warga saja, namun juga antara individu dengan alamnya. Semua masyarakat di Dukuh Wonomulyo bergerak disektor pertanian. Mereka menanam sayur mayur dan jagung. Dalam legenda Dukuh Wonomulyo disebutkan larangan untuk menanam padi dan kelapa. Apabila masyarakat Dukuh Wonomulyo menanam kedua tanaman tersebut akan mendapatkan petaka. Konsep petaka ini terkait dengan kepercayaan dan kesakralan Ki Hajar Wonokoso dalam kehidupan masyarakat Dukuh Wonomulyo. Menurut Koentjaraningrat (1990: 262) masyarakat yang berhadapan dengan hal-hal sakral harus mengindahkan berbagai macam larangan dan pantangan, apabila hal-hal sakral tidak dihadapi dengan hati-hati akan menimbulkan bahaya (Koentjaraningrat, 1990: 262). Larangan menanam padi dan kelapa dipegang kukuh oleh masyarakat dukuh Wonomulyo hingga saat ini.

Terkait dengan larangan untuk menanam padi dan jagung. Secara ilmiah padi dan kelapa merupakan tanaman yang tidak bisa tumbuh di ketinggian lebih dari 1000 mdpl. Dukuh Wonomulyo yang terletak pada ketinggian 1400 mdpl menyebabkan kedua tanaman tersebut tidak bisa tumbuh dengan baik. Sikap patuh masyarakat Dukuh Wonomulyo terhadap larangan yang mundul dalam legenda menunjukkan bahwa apa yang diajarkan oleh Ki Hajar Wonokoso ada kaitannya kebenaran tentang ilmu alam. Masyarakat Dukuh Wonomulyo belajar untuk tidak memaksakan tumbuhan hidup di tempat yang bukan habitatnya. Sifat pasrah dan tidak memaksakan diri walau pun tidak menanam padi inilah yang membuat hasil panen sayur- mayur di Dukuh Wonomulyo menjadi unggul dibandingkan daerah lainnya. Hasil sayur di dukuh Wonomulyo langsung dipasarkan di pasar yang terdapat di dukuh Wonomulyo. Pasar desa menurut Koentjaraningrat (1994: 186) terlatak tidak jauh dari desa dan buka hanya dalam harihari tertentu. Pasar di dukuh Wonomulyo beroperasi setiap hari untuk memasarkan hasil tanaman sayur-mayur mereka. Hasil tanaman inilah yang kemudian dijual kembali oleh tengkulaktengkulak. Pasar desa di dukuh Wonomulyo memiliki peran yang penting bagi seluruh petani di dukuh tersebut.

\section{Simpulan}

Legenda Dukuh Wonomulyo yang terus berkembang dan dipercayai oleh masyarakat pemiliknya memiliki struktur yang menarik. Struktur-struktur tersebut terkait bagaimana hadirnya seorang guru yang mampu menunjukkan jalan menuju keharmonisan hidup. Harmonisai kehidupan tersebut terjalin antara manusia dengan sesama manusia, manusia dengan alamnya dan manusia dengan Tuhannya. Masyarakat Dukuh Wonomulyo meyakini tokoh Ki Hajar Wonokoso dipandang sebagai utusan Tuhan karena telah berhasil menyatukan diri dengan Tuhannya melalui laku.

Tokoh Ki Hajar Wonokoso hadir sebagai sosok guru yang tetap memberikan pengaruh hingga sekarang bagi masyarakat Dukuh Wonomulyo. Seluruh ajaran tentang kebajikan yang diwariskan dan terus diamalkan oleh masyarakat Dukuh Wonomulyo membawa keselamatan dan kedamaian hidup. Munculnya sosok-sosok lain sebagai guru di Dukuh Wonomulyo tidak pernah dianggap mampu bersanding dengan Ki Hajar Wonokoso. Guru-guru baru ini disebut dengan 
pinisepuh yang memiliki tugas sama seperti Ki Hajar Wonokoso, yaitu menjaga keharmonisan Dukuh Wonomulyo.

\section{Daftar Pustaka}

Ahimsa-Putra, H. S. (2006) Strukturalisme Levi-Strauss Mitos dan Karya Sastra. Yogyakarta: Kepel Press.

Danandjaja, J. (2007) Folklor Tionghoa: Sebagai Terapi Penyembuh Amnesia Terhadap Suku Bangsa dan Budaya Tionghoa. Jakarta: Grafiti.

Geertz, C. (1989) Abangan, Santri, Priyayi dalam Masyarakat Jawa. Jakarta: Pustaka Jaya.

Koentjaraningrat (1994) Kebudayaan Jawa. Jakarta: Balai Pustaka.

Koentjaraningrat (1990) Beberapa Pokok Antropologi Sosial. Jakarta: Dian Rakyat.

Laksono, P. M. (2009) Tradisi Dalam Struktur Masyarakat Jawa Kerajaan dan Pedesaan. Yogyakarta: Kepel Pres.

Mulder, N. (2001) Mistisme Jawa; Ideologi di Indonesia. Yogyakarta: LkiS.

Nisa', I. N. F. (2021) Historisitas Penanggalan Jawa Islam. Jurnal El Falaky, 5 (1): 1-28.

Prawiroatmodjo (1981) Bausastra Jawa-Indonesia. Jakarta: Gunung Agung.

Sari, A. P., Arifin, S., dan Rijal, S. (2017) Analisis Cerita Rakyat Kutai Aji Batara Agung Dewa Sakti Ditinjau Dari Fungsi Aspek Mitos Dalam Masyarakatnya. Jurnal Ilmu Budaya, 1 (4): $332-340$.

Soesilo (2005) Kejawen. Yogyakarta: AK Group.

Wiana, K. (2001) Yadnya dan Bhakti. Denpasar: Pustaka Manikgeni.

Woodward, M. (2011). Java, Indonesia and Islam. Arizona State University.

Zoetmulder, P. J dan Robson (2006) Kamus Jawa Kuna Indonesia. Jakarta: Gramedia Pustaka Utama. 